Table 1. Biochemical values in diabetics with and without microangiopathic complications

\begin{tabular}{lcc}
\hline & $\begin{array}{l}\text { Diabetics } \\
\text { with } \\
\text { complications } \\
(n=9)\end{array}$ & $\begin{array}{l}\text { Diabetics } \\
\text { without } \\
\text { complications } \\
(n=9)\end{array}$ \\
\hline$\beta$-Thromboglobulin $(\mathrm{ng} / \mathrm{ml})$ & $61 \pm 49$ & $21 \pm 10^{\mathrm{a}}$ \\
Platelet factor $4(\mathrm{ng} / \mathrm{ml})_{\text {HbA }_{1 \mathrm{c}}(\%)}^{21.6 \pm 17}$ & $5.8 \pm 1.8^{\mathrm{a}}$ \\
Blood glucose $(\mathrm{nmol} / \mathrm{l})_{\text {Creatinine }(\mu \mathrm{mol} / \mathrm{l})}^{7.5 \pm 1.7}$ & $11.4 \pm 5.7$ & $11.7 \pm 3.7^{\mathrm{b}}$ \\
Creatinine clearance $(\mathrm{ml} / \mathrm{min})$ & $103 \pm 43$ & $85 \pm 11^{\mathrm{b}}$ \\
Urea (mmol/l) & $80 \pm 27$ & $88 \pm 19^{\mathrm{b}}$ \\
Triglycerides $(\mathrm{mmol} / \mathrm{l})$ & $9.1 \pm 3.9$ & $7.5 \pm 1.3^{\mathrm{b}}$ \\
Cholesterol $(\mathrm{mmol} / \mathrm{l})$ & $2.2 \pm 1.4$ & $1.3 \pm 0.9^{\mathrm{b}}$ \\
Platelets $\left(\times 10^{9} / 1\right)$ & $5.7 \pm 1.0$ & $5.6 \pm 0.7^{\mathrm{b}}$ \\
Age (years) & $225 \pm 35$ & $222 \pm 44^{\mathrm{b}}$ \\
Duration of diabetes ${ }^{\mathrm{c}}$ (years) & $58 \pm 9$ & $54 \pm 8^{\mathrm{b}}$ \\
& $6 \pm 4$ & $6 \pm 4^{\mathrm{b}}$
\end{tabular}

Results are expressed as mean $\pm \mathrm{SD}$. a $p<0.05$; ${ }^{\text {b }}$ N.S.

${ }^{c}$ In both groups one patient with longer existing diabetes was included (40 years)

abolic control without complications. It is not known whether this phenomenon is a primary or secondary effect of these complications. However, we also studied three siblings of one of our patients with microangiopathic complications, all of whom had Type 1 diabetes without complications. Elevated levels of $\beta$ TG and $\mathrm{PF} 4$ were found suggesting a primary defect of platelet activation in vivo. These higher levels of both $\beta$ TG and PF 4 warrant further investigation of the possible effect of inhibitors of platelet activation in vivo in relation to the course of microangiopathy in diabetes mellitus.

Yours sincerely,

L. D. Elving, A. F. Casparie, K. Miedema and C. J. Russchen

\section{References}

1. Borsey DQ, Dawes J, Fraser DM, Prowse CV, Elton RA, Clarke BF (1980) Plasma beta-thromboglobulin in diabetes mellitus. Diabetologia 18: 353-357

2. Preston FE, Ward JD, Marcola BH, Porter MR, Timperley WR, O'Malley BC (1978) Elevated $\beta$-thromboglobulin levels and circulating aggregates in diabetic microangiopathy. Lancet 1 : 238-240

3. Burrows AW, Chavin SI, Hockaday TDR (1978) Plasmathromboglobulin concentrations in diabetes mellitus. Lancet 1 : 235-237

4. Dawes J, Smith RC, Pepper DS (1978) The release, distribution and clearance of human $\beta$-thromboglobulin and platelet factor 4. Thromb Res 12: 851-861

5. Lokiec F, Najean Y (1980) Intérêt clinique du dosage radioimmunologique de la bèta-thromboglobuline et du facteur plaquettaire 4. Nouv Presse Med 9: 2833-2838

6. Andrassy K, Depperman D, Ritz E, Koderisch J, Seelig H (1980) Different effects of renal failure on beta-thromboglobulin and high affinity platelet factor 4 (HA-PF4) concentrations. Thromb Res 18: 469-475

\section{A. F. Casparie}

Department of Internal Medicine,

Ziekenhuis De Weezenlanden

NL-8011 JW Zwolle, The Netherlands

\title{
Subcutaneous Degradation of Insulin
}

Dear Sir,

A considerable degree of degradation of injected insulin has been demonstrated in pigs [1] and man [2]. Others have published case histories of insulin-dependent diabetics being resistant to subcutaneously injected insulin, but sensitive to intravenously administered insulin $[3,4]$. Is the subcutaneous degradation of insulin really a common clinical problem?

To study the subcutaneous degradation of insulin, highly purified porcine ${ }^{125} \mathrm{I}-\mathrm{NPH}$-insulin was injected into six pigs. Each pig was given five injections of 8 units $(0.2 \mathrm{ml}){ }^{125} \mathrm{I}-\mathrm{NPH}$-insulin $5 \mathrm{~mm}$ beneath the skin. Between one, 180, and $300 \mathrm{~min}$ after injection, subcutaneous tissue around the injection site was removed and insulin extracted with $20 \% \mathrm{CH}_{3} \mathrm{COOH}, 8 \mathrm{~mol} / 1$ urea (unpublished data). No radioactivity was left at the injection site or in the extracted tissue. Radioactivity and immunoreactive insulin in extracts of biopsies from the injection site were determined and correlated as seen in Figure 1. A good correlation was found, indicating only minor accumulation of insulin degradation products in the subcutaneous tissue. In another study a good correlation has been found between disappearance of radioactivity from subcutaneously injected labelled insulin and appearance of immunoreactive insulin in human plasma [5].

Furthermore, insulin requirement per $24 \mathrm{~h}$ during conventional subcutaneous insulin injection treatment was compared with insulin requirement during intravenous insulin infusion in 57 patients with insulin dependent diabetes. Injection treatment was defined as the mean daily insulin dose injected during the last year. All patients were treated with a mixture of highly purified porcine

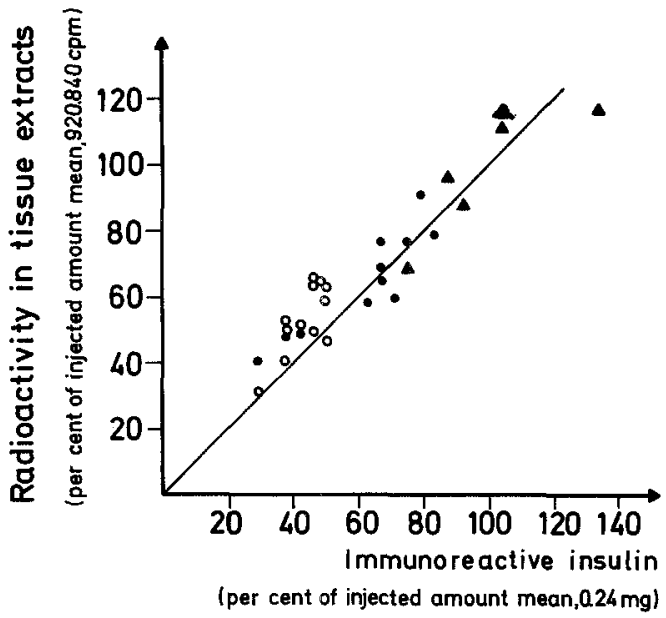

Fig. 1. Radioactivity and immunoreactive insulin in tissue extracts one, 180 and 300 min after subcutaneous injection of 8 units ${ }^{125} \mathbf{I}$ NPH insulin. Percentage of injected mean amount of radioactivity $(920.840 \mathrm{cpm})$ and mean amount of insulin $(240 \mu \mathrm{g}), r=0.94, p$ $<0.001, y=16.5+0.82 x$. The deviation of the regression line from the identity line is not significant $(p>0.05) . \boldsymbol{\Delta}=1 \mathrm{~min}$ after injection. $\bullet=180 \mathrm{~min}$ after injection. $\circ=300 \mathrm{~min}$ after injection 


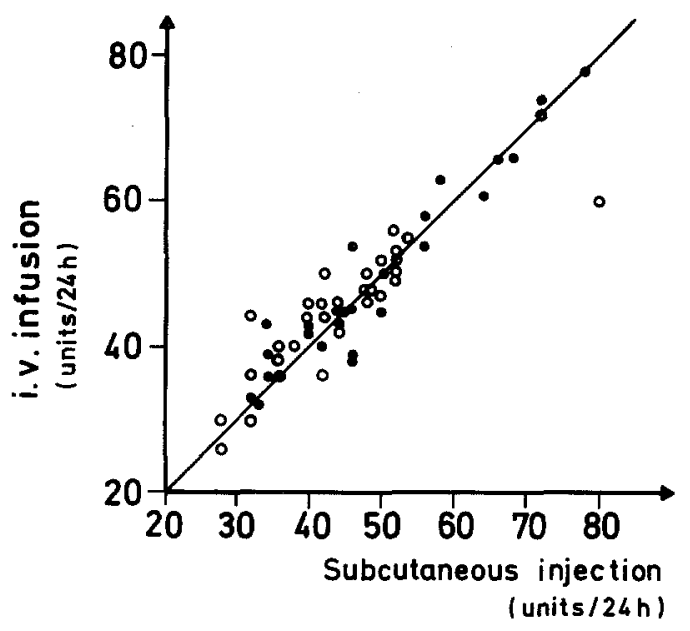

Fig. 2. Insulin requirement per $24 \mathrm{~h}$ in 57 insulin dependent diabetics (no endogenous insulin secretion) during subcutaneous injection therapy and intravenous (iv) infusion therapy $(r=0.922$, $p<0.001, y=8.2+0,84 x) . \bullet$ closed loop, $n=25,0=$ open loop, $n=32$

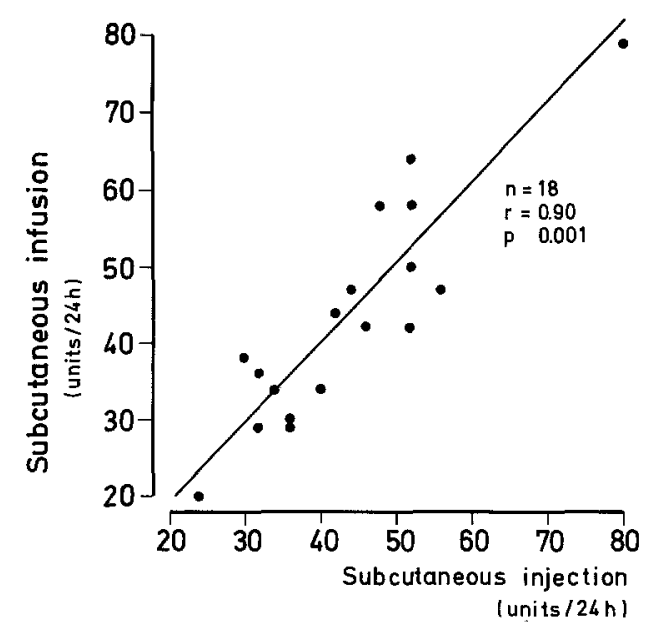

Fig. 3. Insulin requirement per $24 \mathrm{~h}$ in 18 insulin dependent diabetics (no endogenous insulin secretion) during subcutaneous injection therapy and subcutaneous infusion therapy (after 60 days of treatment)

NPH insulin and soluble insulin twice daily. Thirty-two patients were then converted to treatment with an intravenous open-loop system as described previously [6], and 25 patients converted to intravenous insulin treatment with the Biostator (closed-loop) [7]. Capillary blood glucose was nearly normalized by both methods [7].

A significant correlation was found between the subcutaneously injected and the intravenously infused dose of insulin (Fig. 2), indicating only minimal loss of insulin by subcutaneous degradation. Also, the insulin dose before and after converting 18 insulin dependent patients from subcutaneous insulin injection therapy with NPH insulin to subcutaneous infusion with soluble insulin (and near-normalization of glucose) was significantly correlated (Fig. 3), indicating no difference in degradation between NPH and soluble insulin.

Aprotinin (Trasylol) has been postulated to inhibit subcutaneous degradation of insulin, resulting in increased insulin absorption [2]. Therefore, we studied the increase of venous plasma insulin in seven fasting non-obese insulin independent diabetics after sub-

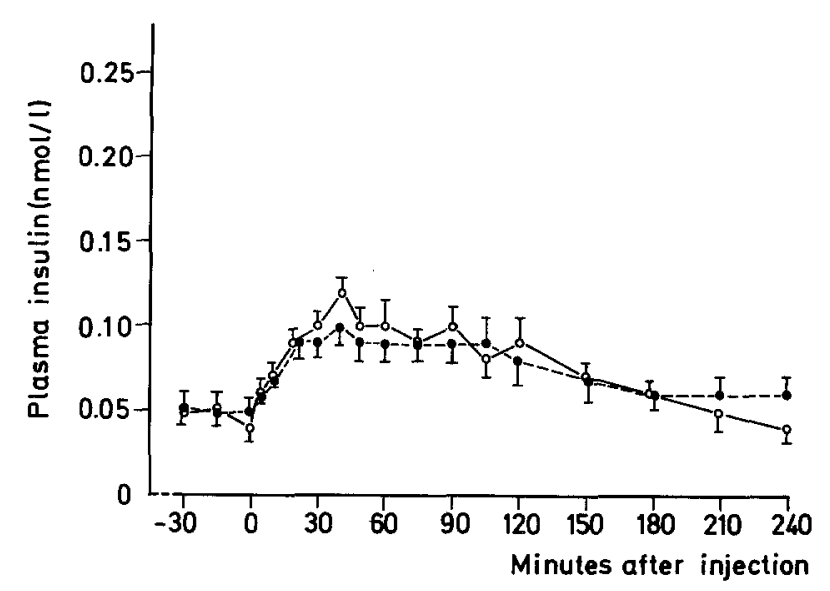

Fig. 4. Plasma immunoreactive insulin in seven insulin independent diabetics before and after subcutaneous injection of 0.05 units highly purified porcine soluble insulin (Leo) per kg body weight with aprotinin 10,000 kallikrein-inactivator units $\bullet-$ and without aprotinin $\bigcirc-0$. Randomized cross over. $\bigcirc$ Soluble insulin. - Soluble + aprotinin. Results expressed as mean \pm SEM

cutaneous injection of 0.05 units $/ \mathrm{kg}$ highly purified porcine soluble insulin in $0.5 \mathrm{ml}$ sodium chloride with and without aprotinin 10,000 Kallikrein-inactivator units. No difference of plasma insulin was found (Fig. 4) indicating no effect of aprotinin on absorption of insulin.

Thus, subcutaneous insulin degradation does not seem to be a major clinical problem.

Yours sincerely,

T. Deckert, B. Hansen, T. Lauritzen and J. Sandahl Christiansen tiansen

\section{References}

1. Berger M, Halban PA, Girardier L, Seydoux J, Offord RE, Renold AE (1979) Absorption kinetics of subcutaneously injected insulin. Evidence for degradation at the injection site. Diabetologia 17: 97-99

2. Berger M, Cüppers HJ, Halban PA, Offort RE (1980) The effect of aprotinin on the absorption of subcutaneously injected regular insulin in normal subjects. Diabetes 29: 81-83

3. Dandona P, Healey F, Foster M, Greenbury E, Beckett AG (1978) Low-dose insulin infusions in diabetic patients with high insulin requirements. Lancet 2: 283-285

4. Paulsen EP, Courtney III JW, Duckworth WC (1979) Insulin resistance caused by massive degradation of subcutaneous insulin. Diabetes 28: 640-645

5. Lauritzen T, Binder C, Faber OK (1980) Importance of insulin absorption, subcutaneous blood flow, and residual beta-cell function in insulin therapy. Acta Paediatr. Scand 283 (Suppl): 81-85

6. Deckert T, Lørup B (1976) Regulation of brittle diabetics by a pre-planned insulin infusion programme. Diabetologia 12: 573-579

7. Deckert T, Bojsen J, Christiansen J Sandahl, Kølendorf K, Svendsen P Aaby, Andersen AR (1980) 24-hour blood glucose profiles in insulin-dependent diabetics treated with intravenous insulin infusion systems. Acta Med Scand 208: 451-458

Dr. T. Deckert

Steno Memorial Hospital

Niels Steensensvej 2

DK 2820 Gentofte, Denmark 